\title{
A preliminary study of water use strategy of desert plants in Dunhuang, China
}

\author{
YongQin CUI ${ }^{1}$, JianYing MA ${ }^{1,2^{*}}$, Wei SUN ${ }^{3}$, JiaHuan $\mathrm{SUN}^{1}$, ZhengHu DUAN ${ }^{1}$ \\ ${ }^{1}$ Cold and Arid Regions Environmental and Engineering Research Institute, Chinese Academy of Sciences, Lanzhou 730000, China; \\ ${ }^{2}$ Xinjiang Institute of Ecology and Geography, Chinese Academy of Sciences, Urumqi 830011, China; \\ ${ }^{3}$ Ministry of Education Key Laboratory of Vegetation Ecology, Institute of Grassland Science, Northeast Normal University, \\ Changchun 130024, China
}

\begin{abstract}
Water is a restrictive factor for plant growth and ecosystem stability in arid and semiarid areas. The dynamics of water availability in soils and water use by plants are consequently critical to ecosystem functions, e.g. maintaining a high resistance to the changing climate. Plant water use strategies, including water-use efficiency (WUE) and the main water source that a plant species utilizes, play an important role in the evaluation of stability and sustainability of a plantation. The water use strategies of desert plants (Tamarix chinensis, Alhagi sparsifolia, Elaeagnus angustifolia, Sophora alopecuroides, Bassia dasyphylla and Nitraria sphaerocarpa) in three different habitats (saline land, sandy land and Gobi) in Dunhuang (located in the typical arid area of northwestern China) were studied. The stable isotope of oxygen was used to determine the main water source and leaf carbon isotope discrimination was used to estimate the long-term WUE of plant species in the summer of 2010. The results suggest that: 1) the studied desert plants took up soil water below the depth of $80 \mathrm{~cm}$; 2) T. chinensis in the three habitats used deeper soil water and T. chinensis in the Gobi site had higher WUE than those in the saline land and the sandy land. The results indicated that desert plants in Dunhuang depended on stable water source and maintained high WUE to survive in water limited environments.
\end{abstract}

Keywords: desert plant; stable isotope; water source; water-use efficiency; Dunhuang

Citation: YongQin CUI, JianYing MA, Wei SUN, JiaHuan SUN, ZhengHu DUAN. 2015. A preliminary study of water use strategy of desert plants in Dunhuang, China. Journal of Arid Land, 7(1): 73-81. doi: 10.1007/s40333-014-0037-1

Water plays an important role in plant growth and ecosystem functioning. In arid and semiarid areas, plant communities are often exposed to water stress which may be critical and act to select appropriate adaptive strategies (Fischer and Turner, 1978; Downing et al., 1997; Chaves et al., 2002; Lioubimtseva and Henebry, 2009). The intrinsic specialization of desert plant communities to these extreme habitats implicates high vulnerability to any climate changes. Increasing exploitation of groundwater and possible climatic changes that may increase drought and temperature could severely injure plants and therefore impact these valuable ecosystems (Alessio et al.,
2004). Thus, it is important to have a comprehensive understanding concerning water use strategies of plants in water limited environments.

Stable isotope is a robust tool that has been widely used to the study of plant water use (Ehleringer and Dawson, 1992). Due to physical and climatic factors, different water resources are characterized by different isotopic signatures for both ${ }^{18} \mathrm{O} /{ }^{16} \mathrm{O}$ and $\mathrm{D} / \mathrm{H}$ ratios (Craig, 1961; Dansgaard, 1964). Moreover, there is generally no stable isotope fractionation during the process of water uptake by terrestrial plants. Thus, xylem water can reflect the isotopic compositions of water sources used by plant species in most

*Corresponding author: JianYing MA (E-mail: jyma@ms.xjb.ac.cn)

The first and third authors contributed equally to this work.

Received 2014-02-27; revised 2014-06-16; accepted 2014-06-28

(C) Xinjiang Institute of Ecology and Geography, Chinese Academy of Sciences, Science Press and Springer-Verlag Berlin Heidelberg 2015 
cases (Wershaw et al., 1966; Zimmermann et al., 1967; Allison et al., 1983; White et al., 1985; Dawson and Ehleringer, 1991; Dawson et al., 1993, 2002). Nevertheless, previous studies showed that some halophytic and xerophytic species might possess the capacity to discriminate against deuterium isotopes during soil water uptake by plant roots (Sternberg and Swart, 1987; Sternberg et al., 1991; Lin and Sternberg, 1992; Ellsworth and Williams, 2007); while the oxygen isotopic composition of xylem water is always in accordance with the water source used by plants (Alessio et al., 2004). Therefore, in this study, $\delta^{18} \mathrm{O}$ values were chosen as a measure of interspecific differences in source water. Moreover, long-term water-use efficiency (WUE) of $\mathrm{C}_{3}$ species can be evaluated by means of carbon isotope discrimination analysis of leaf tissues (O'Leary, 1988; Farquhar et al., 1989). Extensive studies have been conducted to examine plant water use using stable isotope techniques in arid and semiarid ecosystems in USA (Lite et al., 2005; Schwinning et al., 2005; Stromberg et al., 2005; Nippert and Knapp, 2007), Australia (Dawson and Pate, 1996) and northern China (Ohte et al., 2003; Li et al., 2007; Duan et al., 2008; Yang et al., 2011; Jia et al., 2012). In drought-prone ecosystems, different plant species in the same habitat may utilize water from different sources. Flanagan et al. (1992) observed that Juniperinus osteosperma would take up summer precipitation, but Chrysothamnus nauseosus used the groundwater in semi-arid pinyon-juniper woodland in southern Utah. In a study from the Mediterranean macchia ecosystem of Italy, Valentini et al. (1992) showed that Pistacia lentiscus, Phyllirea angustifolia and Quercus ilex depended more on rain water utilization; whereas Quercus pubescens and Quercus cerris mainly used groundwater during the summer drought. The same plant species growing in different habitats also have different water uptake patterns. Zhou et al. (2011) demonstrated that, at the Hanggin Banner site, $\mathrm{Ni}$ traria tangutorum and Artemisia ordosica depended mainly on shallow soil water, while at the Dengkou and Minqin sites both species obtained water from deep soil layers or groundwater. Despite these efforts, only a few studies employing such methods have emphasized to date in China (Cheng et al., 2006; Zhu et al., 2010; Yang et al., 2011; Zhou et al., 2013). There have been far fewer studies focusing on the water use of species in extremely arid ecosystems, like Dunhuang, Gansu province.

The aim of the present study is to characterize the functional patterns of water sources exploitation and water-use efficiency of several dominant species in three different habitats (saline land, sandy land and Gobi) in Dunhuang area using a stable isotope approach. Specially, we want to address the following two research questions: First, in the same habitat, do the desert plant species use the soil water of $0-80 \mathrm{~cm}$, and if they do, do they take up water from different soil depths? Second, do the common desert plant species growing in the three different habitats differ in water use efficiency and water source? This work will be helpful for us to fully understand responses of species to ongoing climate changes and to assess changes of vegetation distribution in semiarid and arid areas in the future. Meanwhile, it can provide theoretical guidance for water-saving techniques in arid areas and contribute to understanding of the water cycle in desert ecosystems.

\section{Materials and methods}

\subsection{Study area}

This study was carried out in Dunhuang area $\left(39^{\circ} 40^{\prime}-41^{\circ} 35^{\prime} \mathrm{N}, 92^{\circ} 13^{\prime}-95^{\circ} 30^{\prime} \mathrm{E} ; 1,138 \mathrm{~m}\right.$ asl) located in the westernmost point of Hexi Corridor of Gansu province, northwestern China (Fig. 1). It is characterized by a warm temperate continental arid climate with sparse rainfall and intense evaporation. Annual mean temperature (MAT) is $9.8^{\circ} \mathrm{C}$. Mean annual precipitation and mean annual evaporation from 1938 to 2003 are 39.8 and 2,486 mm, respectively (Zhang, 2008). The monthly distribution of precipitation for 2010 and seasonal variation in precipitation and air temperature from 1971 to 2000 are shown in Fig. 2. The data were obtained from the National Meteorological Information Centre, China Meteorological Administration. 


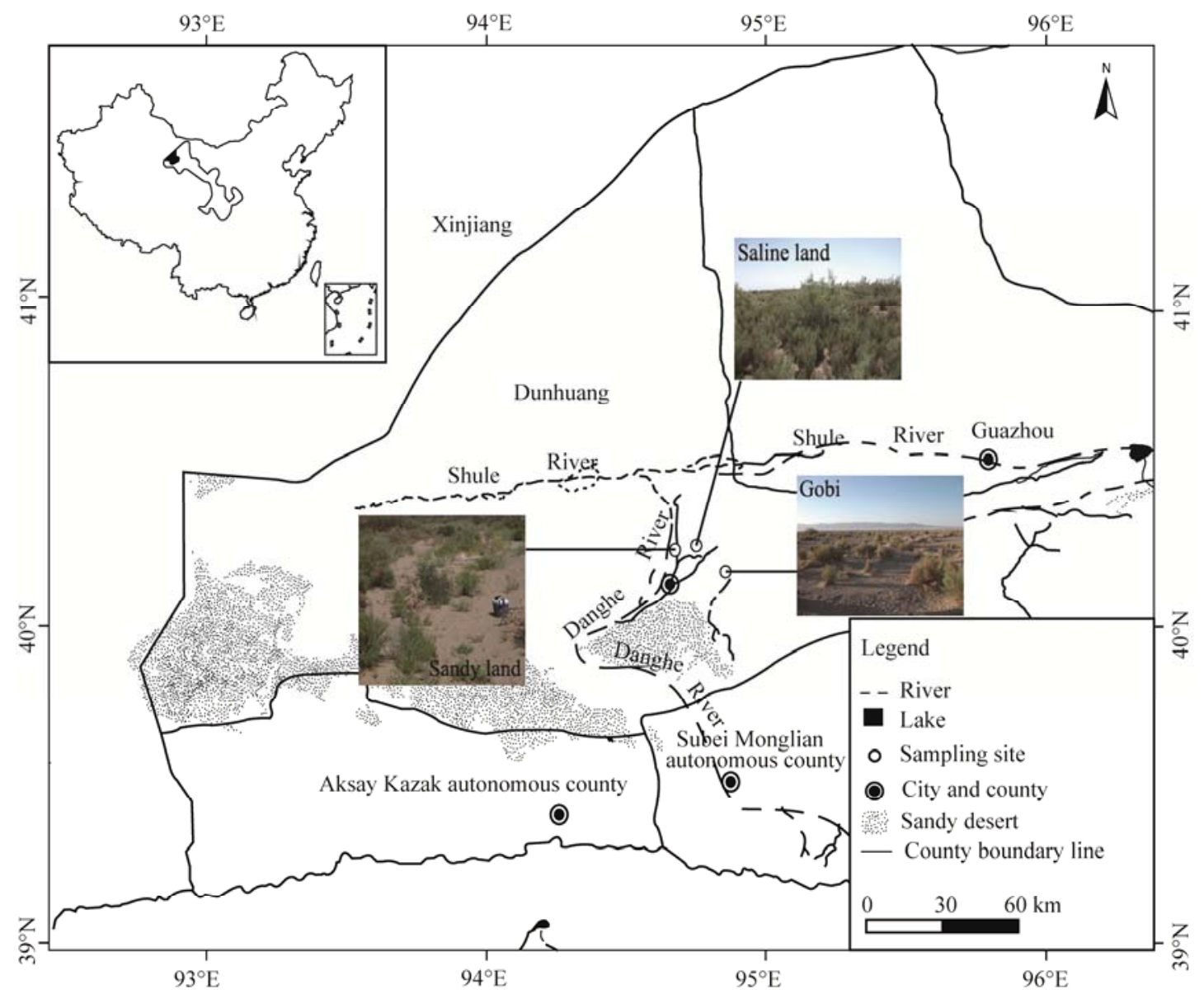

Fig. 1 Map of the study area and location of study sites

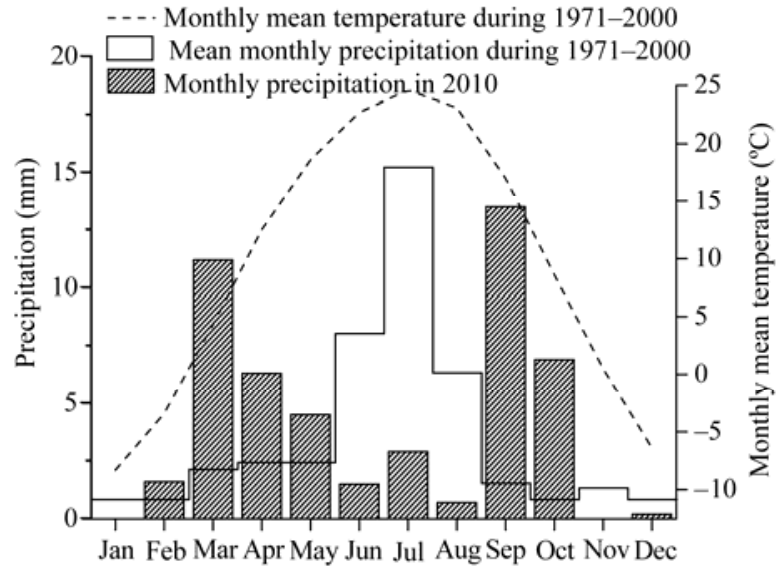

Fig. 2 The distribution of monthly precipitation for $2010 \mathrm{com}$ pared to the long-term mean monthly precipitation (1971-2000) (solid line) and the long-term monthly mean temperature (1971-2000) (dash line) in Dunhuang, China

In Dunhuang area, saline land, sandy land and Gobi are the common land types, which account for a larger proportion of the total land area (Sang, 2006). Therefore, typical desert plant communities for saline land, sandy land and Gobi were selected to carry out our field experiments. These study sites are mainly vegetated by shrubs or grasses, with the same climate. Water resources of the studied area are composed of rainfall, surface water and groundwater. For this study, we ignored the effects of rainfall on soil water and groundwater because mean annual precipitation is only $39.8 \mathrm{~mm}$.

\subsection{Field sampling}

Plant and soil sampling was conducted on 21-23 August 2010. In each study site, three dominant plant species were selected for the study of water use strategies. A common species, Tamarix chinensis, was sampled in all study sites (Table 1).

Sampling of twig xylem water was conducted at midmorning $(10: 00 \mathrm{am})$ when plants reached stable isotope equilibrium status. Stem segments (without leaves) of several centimeters from the shoot tip were taken for avoiding influence on water sources from the 
Table 1 Geographic characteristics of site location, soil texture, plant species and life form

\begin{tabular}{|c|c|c|c|c|c|}
\hline Site & Location & Altitude (m) & Soil texture & Species & Life form \\
\hline \multirow{3}{*}{ Saline land } & \multirow{3}{*}{$\begin{array}{l}40.24^{\circ} \mathrm{N} \\
94.72^{\circ} \mathrm{E}\end{array}$} & \multirow{3}{*}{1,110} & \multirow{3}{*}{$\begin{array}{l}\text { Top: sandy soil } \\
\text { Deep: silt clay }\end{array}$} & Tamarix chinensis & Shrub \\
\hline & & & & Alhagi sparsifolia & Shrub \\
\hline & & & & Elaeagnus angustifolia & Shrub \\
\hline \multirow{3}{*}{ Sandy land } & \multirow{3}{*}{$\begin{array}{l}40.21^{\circ} \mathrm{N} \\
94.68^{\circ} \mathrm{E}\end{array}$} & \multirow{3}{*}{1,108} & \multirow{3}{*}{ Sandy soil } & T. chinensis & Shrub \\
\hline & & & & Sophora alopecuroides & Grass \\
\hline & & & & Bassia dasyphylla & Grass \\
\hline \multirow{3}{*}{ Gobi } & \multirow{3}{*}{$\begin{array}{l}40.17^{\circ} \mathrm{N} \\
94.84^{\circ} \mathrm{E}\end{array}$} & \multirow{3}{*}{1,099} & \multirow{3}{*}{$\begin{array}{l}\text { Mixture of very coarse } \\
\text { sands and gravels }\end{array}$} & T. chinensis & Shrub \\
\hline & & & & Nitraria sphaerocarpa & Shrub \\
\hline & & & & A. sparsifolia & Shrub \\
\hline
\end{tabular}

leaves. The stem segments were $3-5 \mathrm{~mm}$ in diameter and $5 \mathrm{~cm}$ in length. Stem samples were immediately enclosed in screw-cap glass vials, wrapped with parafilm, and placed in a cooler with ice for transportation to the laboratory. In the laboratory, samples were stored in freeze for later water extraction. For each species, three individual plants were sampled repeatedly.

Soil samples were collected with a hand auger at depths of $0-5,5-10,10-20,20-40,40-60$ and $60-80$ $\mathrm{cm}$ in each site. These samples were separated into two parts: one was sealed in capped vials, wrapped with parafilm and stored in freeze for soil water oxygen isotope analysis; the other part was sealed in soil tins for subsequent analysis of gravimetric water content (percentage water, measured as $\mathrm{g}$ water/g dry soil $\times 100 \%)$. Three soil cores were taken randomly in each site except Gobi. In Gobi only one soil core was taken due to its uniformity of the landscape in vast area and the underlying rock. Reservoir water was obtained from an irrigation ditch close to sandy land which delivers water from Danghe reservoir.

Leaf samples for carbon isotope analysis were also collected in the three sites. Fully expanded, sunny side leaves from at least 10 individuals of each plant species were collected in each site to make one composite sample for carbon isotope composition analysis. Leaf samples were dried at $70^{\circ} \mathrm{C}$ to a constant weight, and then ground to 80 meshes for carbon isotope composition analysis. Three replicates for each species were collected in each study site.

\subsection{Stable isotope analysis}

All water samples were extracted using a cryogenic vacuum distillation apparatus (Ehleringer et al., 2000) and analyzed for oxygen isotope ratios $\left(\delta^{18} \mathrm{O}\right)$ using an elemental analyzer (Flash EA1112 HT, Thermo Fisher Scientific, Inc., Waltham, MA, USA) coupled to an Isotope Ratio Mass Spectrometer (DELTA V Advantage, Thermo Fisher Scientific, Inc., Waltham, MA, USA). Oxygen isotope measurements were expressed in common $\delta$ notation. $\delta^{18} \mathrm{O}$ was referenced to $\mathrm{V}-\mathrm{SMOW}$ with measuring precision of $0.2 \%$.

Analyses of carbon isotope values of leaf samples were performed by a continuous flow isotope ratio mass spectrometer (Delta PlusXP, Thermo Finnigan, Bremen, Germany) coupled with an elemental analyzer (ECS 4010, Costech Analytical, Valencia, CA). Stable carbon isotope values were expressed as $\delta^{13} \mathrm{C}$ values relative to the VPDB (Vienna Peedee Belemnite) standard, with measuring precision of $0.2 \%$.

\subsection{Data analysis}

One-way analysis of variance (ANOVA) by SPSS 17.0 software was applied to compare the variation of soil water content (SWC) and $\delta^{18} \mathrm{O}$ values of soil water among different soil depths, and the differences of $\delta^{13} \mathrm{C}$ values of leaves, $\delta^{18} \mathrm{O}$ values of xylem water among different species or among different habitats. If the effect was statistically significant $(P<0.05)$, a least significant difference (LSD) multiple range test was used to compare the difference. SWC, $\delta^{18} \mathrm{O}$ values of soil water and xylem water, and $\delta^{13} \mathrm{C}$ values of leaves are expressed as mean \pm SE.

\section{Results and discussion}

\subsection{Soil water content}

Soil water content (SWC) differed significantly among the three study sites $(P<0.001)$. SWC of the 
saline land was significantly higher than those of the sandy land and the Gobi site $(P<0.001)$. There were no significant differences in SWC between the sandy land and the Gobi site (Fig. 3). In the saline land, sandy soil composed the topsoil and silt clay composed the deep soil; whereas the major component of soil in the sandy land was dry sand and soil in the Gobi site was characterized by a mixture of very coarse sand and gravel from 0 to $80 \mathrm{~cm}$ depth (Table 1). Soils in the sandy land and the Gobi site had poor water retention capability compared to that of the saline land.

Additionally, SWC in the saline land increased with soil depths (Fig. 3). This is mainly attributed to sparse rainfall and strong evaporation: the topsoil affected by stronger evaporation had less soil water content, while SWC in the deep layer was less influenced by evaporation. We separated the soil profile into two groups, 0-20 and $20-80 \mathrm{~cm}$ basing on soil water content. The SWC of 0-20 $\mathrm{cm}$ was obviously lower than that of $20-80 \mathrm{~cm}(P<0.05)$. Moreover, in sites of either sandy

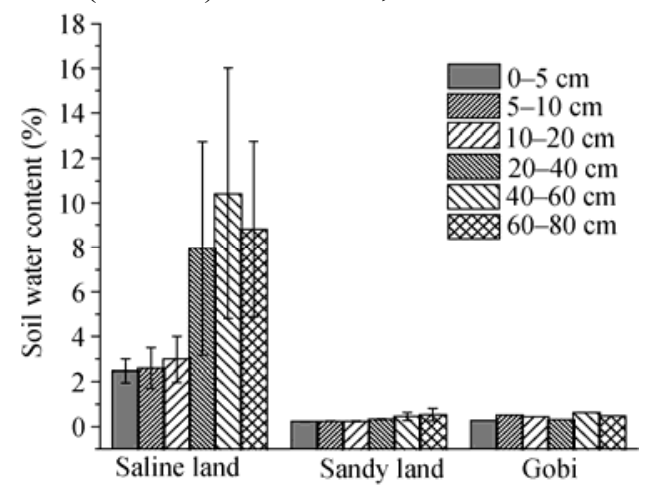

Fig. 3 Soil water content of different soil depths in the saline land, sandy land and Gobi site land or Gobi no apparent variation was observed in SWC among different soil layers. Soil water contents in the sandy land increased only by $0.34 \%$ from $0-20$ to $60-80 \mathrm{~cm}$ layer. This is probably a consequence of soil texture as soil in the sandy land is mainly composed of dry sand, which has low water retention capacity.

\section{$2.2 \delta^{18} \mathrm{O}$ of soil water}

$\delta^{18} \mathrm{O}$ of soil water showed a sharp change along the soil profiles in the saline land and the sandy land. As shown in Fig. 4a, the $\delta^{18} \mathrm{O}$ values of soil water in the saline land exhibited significant variation $(P<0.05)$ along soil depths. The $\delta^{18} \mathrm{O}$ values increased from $-0.3 \%$ at $0-5 \mathrm{~cm}$ depth to $7.77 \%$ at $20-40 \mathrm{~cm}$ depth, and then decreased to $-2.11 \%$ at $60-80 \mathrm{~cm}$ depth. In the sandy land, the $\delta^{18} \mathrm{O}$ values of soil water reached the most positive value at $40-60 \mathrm{~cm}$, and then decreased to $-0.43 \%$ (Fig. $4 \mathrm{~b}$ ). However, there was no marked variation in $\delta^{18} \mathrm{O}$ values $(P=0.672)$ among different soil depths in the sandy land.

Previous study suggested the position of the maximum values in the isotope profile could be used to determine the depth of the evaporating front (Allison, 1998). Our results indicated that the evaporating front in the saline land existed at $20-40 \mathrm{~cm}$ soil layer, and in the sandy land at $40-60 \mathrm{~cm}$ soil layer. Above the evaporating front, the $\delta^{18} \mathrm{O}$ values of soil water increased with the increasing of soil depths and water isotope movement was mainly in the vapour phase; whereas, beneath the evaporating front the isotope signatures of soil water decreased with the increasing of soil depths and dominated by liquid transport

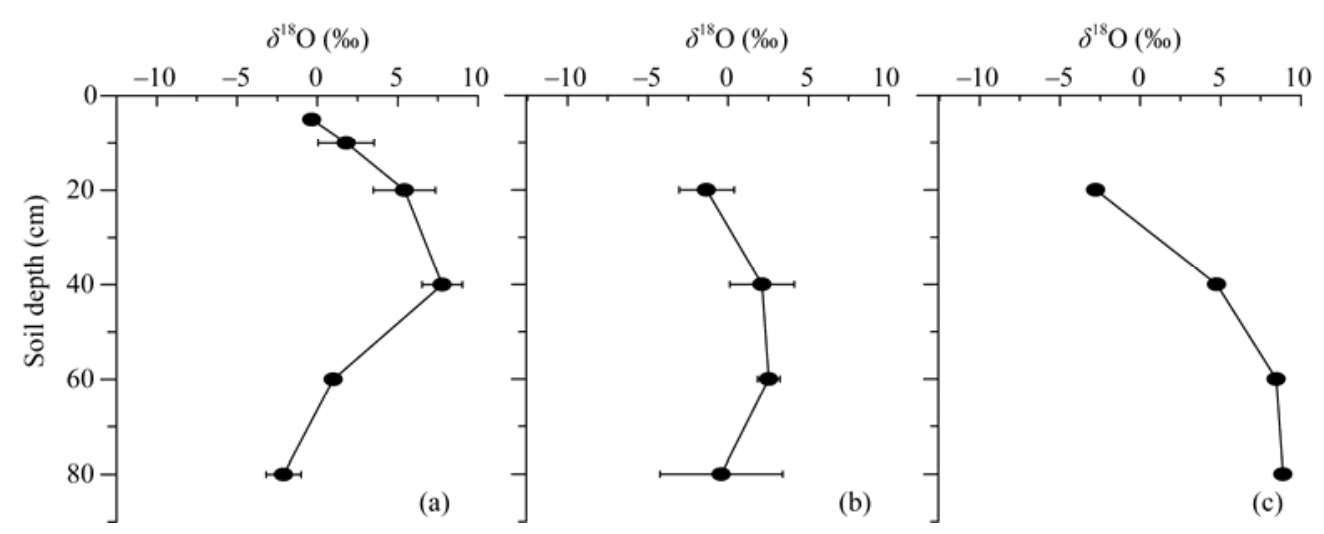

Fig. 4 The $\delta^{18} \mathrm{O}$ values of soil water in the saline land (a), sandy land (b) and Gobi site (c) 
(Barnes and Allison, 1983; Allison, 1998; Kendall and McDonnell, 1998). A similar profile of soil water $\delta^{18} \mathrm{O}$ values was reported in a study of water sources of Gobi plants in middle reaches of the Heihe River (Yu et al., 2012). In the Gobi site, $\delta^{18} \mathrm{O}$ values increased with the increasing of soil depth (Fig. 4c). The water stable isotope profile can be used to determine the depth of an evaporating front in the soil, which is particularly useful for comparing the effects of evaporation among different sites (Newman et al., 1997). In Fig. 4, the evaporating front was not detected among 0-80 cm soil layers in Gobi site; we can infer that the evaporating front located in even deeper soil layer $(>80 \mathrm{~cm})$ in Gobi site. Moreover, the evaporating front existed above $60 \mathrm{~cm}$ soil layer in the saline land and sandy land (Fig. 4). Therefore, the effects of evaporation in Gobi site were greater than in the saline land and sandy land. In addition, in the sandy land, $\delta^{18} \mathrm{O}$ values of the reservoir water were relatively negative in comparison with those of soil water, suggesting that significant evaporative isotope fractionations existed during the process of hydraulic infiltration from reservoir water to soil water.

We estimated $\delta \mathrm{D}$ and $\delta^{18} \mathrm{O}$ for Dunhuang area and created the predicted Local Meteoric Water Line (pLMWL) using the Online Isotopes in Precipitation Calculator (OIPC; http://www.waterisotopes.org/). The Global Meteoric Water Line (GMWL: $\delta \mathrm{D}=8\left(\delta^{18} \mathrm{O}\right)+10 ;$ Dansgaard, 1964), the pLMWL $\left(\delta \mathrm{D}=7.363\left(\delta^{18} \mathrm{O}\right)+3.581, R^{2}=0.99, P<0.01\right)$ and the isotopic values of soil water, xylem water are shown in Fig. 5. The isotopic compositions of soil and xylem water in the three study sites were in the area below the GMWL and pLMWL. The slope of the best fit line representing the $\delta \mathrm{D}-\delta^{18} \mathrm{O}$ relationship for soil water $\left(\delta \mathrm{D}=2.589\left(\delta^{18} \mathrm{O}\right)-59.452, R^{2}=0.84, P<0.01\right)$ was even lower than that of GMWL and pLMWL. The $\delta \mathrm{D}$ and $\delta^{18} \mathrm{O}$ values of xylem water were all more negative than those of soil water. These results indicated that soil water affected by very strong evaporation enrichment and reflected the extremely dry conditions.

\subsection{Water sources of desert plants}

Soil water is one of the most important sources that desert plants can use in arid and semiarid regions. In the three studied sites the isotope values of all plants were more negative than that of soil water $(0-80 \mathrm{~cm})$, which suggest that all desert plants extracted soil

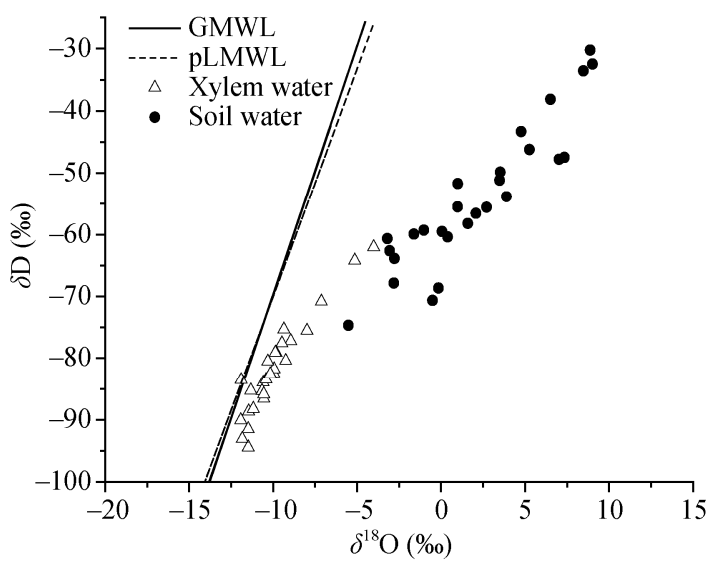

Fig. 5 Relationship between $\delta \mathrm{D}$ and $\delta^{18} \mathrm{O}$ in soil water and xylem water. The Global Meteoric Water Line (GMWL) and the predicted Local Meteoric Water Line (pLMWL) were also presented.

water below the depth of $80 \mathrm{~cm}$ (Fig. 4; Table 2). Furthermore, $\delta^{18} \mathrm{O}$ value of xylem water differed markedly among species in the saline land and the Gobi site, suggesting that coexisting plant species had different water sources.

Table 2 The $\delta^{18} \mathrm{O}$ values of plant xylem water in the saline land, sandy land and Gobi site

\begin{tabular}{lcc}
\hline Site & Species & $\delta^{18}$ O value of xylem water \\
& & $(\%)$ \\
\hline Saline land & T. chinensis & $-11.07 \pm 0.27^{\mathrm{a}}$ \\
& A. sparsifolia & $-10.07 \pm 0.17^{\mathrm{b}}$ \\
Eandy land & E. angustifolia & $-9.91 \pm 0.33^{\mathrm{b}}$ \\
& S. chinensis & $-11.35 \pm 0.38^{\mathrm{a}}$ \\
Gobi & B. dasyphylla & $-11.34 \pm 0.39^{\mathrm{a}}$ \\
& T. chinensis & $-9.98 \pm 0.35^{\mathrm{a}}$ \\
& N. sphaerocarpa & $-11.06 \pm 0.58^{\mathrm{a}}$ \\
& A. sparsifolia & $-6.17 \pm 1.63^{\mathrm{b}}$ \\
\end{tabular}

Note: Different lowercases represent significant differences of $\delta^{18} \mathrm{O}$ values of different species in the same site $(P<0.05)$. Data are means \pm SE.

In the saline land, the studied three species had more negative $\delta^{18} \mathrm{O}$ values, compared to soil water $(0-80 \mathrm{~cm}): T$. chinensis had the lowest $\delta^{18} \mathrm{O}$ values of xylem water among the three species, indicating that $T$. chinensis may take up soil water of deeper layers $(>80$ $\mathrm{cm})$ than the other two plants; while A. sparsifolia and $E$. angustifolia mainly used soil water of shallower layers and they shared soil water of the similar soil depth. 
In the sandy land, there were no significant differences observed in $\delta^{18} \mathrm{O}$ values among the three species $(P=0.073)$ and their $\delta^{18} \mathrm{O}$ values all below the values of reservoir water and soil water $(0-80 \mathrm{~cm})$, suggesting the three studied species used deeper soil water of similar soil depth $(>80 \mathrm{~cm})$, but didn’t use reservoir water and soil water from $0-80 \mathrm{~cm}$.

As shown in Fig. 4c and Table 2, in the Gobi site, compared to the isotope ratios of soil water, the $\delta^{18} \mathrm{O}$ values of the three species were more negative than that of soil water $(0-80 \mathrm{~cm})$. The $\delta^{18} \mathrm{O}$ values of $T$. chinensis were significantly lower than those of $N$. sphaerocarpa and A. sparsifolia while there was no significant difference between the latter two species. Therefore, $T$. chinensis is likely to utilize deeper soil water $(>80 \mathrm{~cm})$ or/and groundwater; while $N$. sphaerocarpa in the Gobi site may use the shallower soil water than that of T. chinensis.

There was no remarkable variation in the $\delta^{18} \mathrm{O}$ values of $T$. chinensis among the three sites $(P=0.913)$, and in each study site the $\delta^{18} \mathrm{O}$ values of $T$. chinensis were more negative than the other two species (Table 2). The results indicated that $T$. chinensis adapt to the three different habitats and use the deepest soil water, compared to the other two species in each site.

\subsection{Water-use efficiencies of desert plants}

Carbon isotope analysis adds further insight to our understanding of the diversity of the water use patterns of desert species. Carbon isotope ratios of leaves ranged from $-28.4 \%$ to $-24.7 \%$ (Fig. 6), indicating all these desert plants are $C_{3}$ plants (O'Leary, 1981). The range is generally consistent with previously published $\delta^{13} \mathrm{C}$ values of some desert plants from other arid regions of the world (Ehleringer and Cooper, 1988; Rundel, 1999). Compared to the average value $\left(-28.14 \%\right.$ o of plants $\delta^{13} \mathrm{C}$ for a global investigation (Laundré, 1999), the average value $(-26.70 \%$ ) of plants $\delta^{13} \mathrm{C}$ in this study is more positive.

In the saline land, greater variation in $\delta^{13} \mathrm{C}$ value was detected among the three plant species $(P<0.05)$. The $\delta^{13} \mathrm{C}$ values of $A$. sparsifolia leaves were significantly lower than those of T. chinensis. However, no significant difference in $\delta^{13} \mathrm{C}$ value was detected between E. angustifolia and A. sparsifolia or $T$. chinensis (Fig. 6). In sandy land, there was no remarkable significance among three different plant

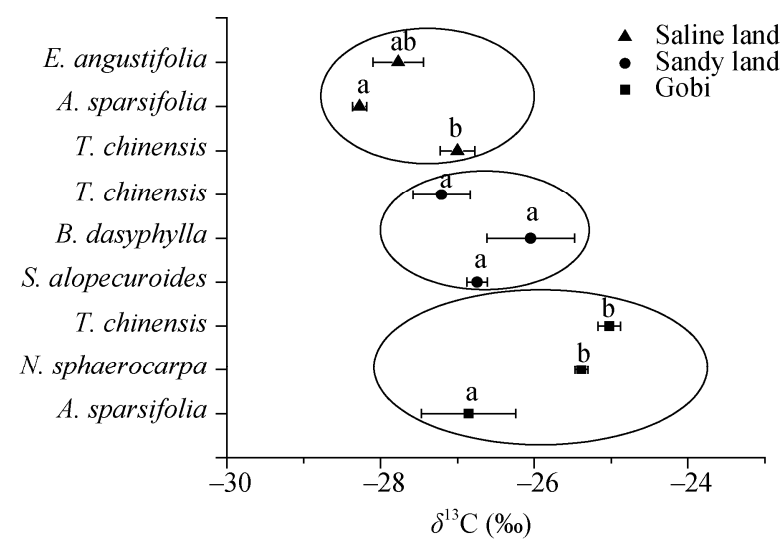

Fig. 6 Leaf $\delta^{13} \mathrm{C}$ values (mean $\pm \mathrm{SE}$ ) of the studied desert communities in Dunhuang area. Different lowercase letters indicate significant difference in $\delta^{13} \mathrm{C}$ values between plant species in each studied site at $P<0.05$ level.

species $(P=0.2)$. In Gobi, the foliar $\delta^{13} \mathrm{C}$ ratio of $A$. sparsifolia was significantly lower than those of $T$. chinensis $(P<0.05)$ and $N$. sphaerocarpa $(P<0.05)$, and the carbon isotope values were similar between $T$. chinensis and $N$. sphaerocarpa $(P=0.512)$.

The $\delta^{13} \mathrm{C}$ values of $T$. chinensis were differed significantly among the three sites $(P<0.01)$. The $\delta^{13} \mathrm{C}$ values of $T$. chinensis in the Gobi site were significantly more positive than those in other two sites, and the $\delta^{13} \mathrm{C}$ values of $T$. chinensis in the saline land were similar to those in the sandy land. So we conclude that T. chinensis in the Gobi site had higher WUE than those in the saline land and the sandy land; whereas $T$. chinensis in the saline land and the sandy land had similar WUE. This is mainly related to drought stress: SWC in the Gobi site was markedly lower than that of the saline land. Other studies got similar results, i.e. in northwestern China, the foliar $\delta^{13} \mathrm{C}$ values increased significantly with decreasing soil water content (Wang et al., 2005; Ma et al., 2007).

\section{Conclusions}

In Dunhuang area, the studied desert plants did not use soil water from $0-80 \mathrm{~cm}$, but relied more on stable water source such as deeper soil water $(>80 \mathrm{~cm})$ or/and groundwater in summer of 2010. By combining the analysis of plant water sources in each site, the following results have been got that: in the saline land T. chinensis used the deepest soil water; in the sandy land three species sucked up soil water of similar soil 
depths; in the Gobi site T. chinensis relied on deeper soil water, compared to the other two species. All species investigated had high WUE. Furthermore, $T$. chinensis, the common species, whose WUE increased with decreasing soil water content, always took up deeper soil water than other species and had higher WUE, indicating it was well adapt for dry climate. The potential mechanism of plant water uptake patterns in Dunhuang area is likely related to extremely arid climate and soil properties. Despite its preliminary character, this study improved our understanding of the water use strategies of desert plants in Dunhuang area.

\section{Acknowledgements}

The research was supported by the National Natural Science Foundation of China (41071032, 31270445), the Program for New Century Excellent Talents in University (NCET-12-084), the Thousand Talents Program of China (2013) and the West Light Foundation of the Chinese Academy of Sciences (2009). We would like to thank XiaoNing LIU and Qiao ZENG for help during field and laboratory work.

\section{References}

Alessio G A, Lillis M, Brugnoli E, et al. 2004. Water sources and water-use efficiency in Mediterranean coastal dune vegetation. Plant Biology, 6(3): 350-357.

Allison G B, Barnes C J, Hughes M W. 1983. The distribution of deuterium and ${ }^{18} \mathrm{O}$ in dry soils 2 . Experimental. Journal of Hydrology, 64(1): 377-397

Allison G B. 1998. Stable isotopes in soil and water studies. In: Causse E C, Gasse F. Hydrology and Isotope Geochemistry. Paris: Orstom Editions, 23-38.

Barnes C J, Allison G B. 1983. The distribution of deuterium and ${ }^{18} \mathrm{O}$ in dry soils 1 . Theory. Journal of Hydrology, 60(1-4): 141-156.

Bazzaz F A. 1996. Plants in Changing Environments: Linking Physiological, Population, and Community Ecology. New York: Cambridge University Press.

Chaves M M, Pereira J S, Maroco J, et al. 2002. How plants cope with water stress in the field? Photosynthesis and growth. Annals of Botany, 89(7): 907-916.

Cheng X L, An S Q, Li B, et al. 2006. Summer rain pulse size and rainwater uptake by three dominant desert plants in a desertified grassland ecosystem in northwestern China. Plant Ecology, 184(1): $1-12$.

Craig H. 1961. Isotopic variations in meteoric waters. Science, 133(3465): 1702-1703.

Dansgaard W. 1964. Stable isotopes in precipitation. Tellus, 16(4): 436-468.

Dawson T E, Ehleringer J R. 1991. Streamside trees that do not use stream water. Nature, 350(6316): 335-337.
Dawson T E. 1993. Water sources of plants as determined from xylem-water isotopic composition: perspectives on plant competition, distribution, and water relations. In: Ehleringer J R, Hall A E, Farquhar G D. Stable Isotopes and Plant Carbon-water Relations. San Diego: Academic Press, 465-496.

Dawson T E, Pate J S. 1996. Seasonal water uptake and movement in root systems of Australian phraeatophytic plants of dimorphic root morphology: a stable isotope investigation. Oecologia, 107(1): 13-20.

Dawson T E, Mambelli S, Plamboeck A H, et al. 2002. Stable isotopes in plant ecology. Annual Review of Ecology and Systematics, 33: 507-559.

Downing T E, Ringius L, Hulme M, et al. 1997. Adapting to climate change in Africa. Mitigation and Adaptation Strategies for Global Change, 2(1): 19-44.

Duan D Y, Ouyang H, Song M H, et al. 2008. Water sources of dominant species in three alpine ecosystems on the Tibetan Plateau, China. Journal of Integrative Plant Biology, 50(3): 257-264.

Ehleringer J R, Cooper T A. 1988. Correlations between carbon isotope ratio and microhabitat in desert plants. Oecologia, 76(4): 562-566.

Ehleringer J R, Dawson T E. 1992. Water uptake by plants: perspectives from stable isotope composition. Plant, Cell and Environment, 15(9): 1073-1082.

Ehleringer J R, Roden J, Dawson T E. 2000. Assessing ecosystem-level water relations through stable isotope ratio analyses. In: Sala O E, Jackson R B, Mooney H A, et al. Methods in Ecosystem Science. Heidelberg: Springer New York, 181-198.

Ellsworth P Z, Williams D G. 2007. Hydrogen isotope fractionation during water uptake by woody xerophytes. Plant and Soil, 291(1): 93-107.

Farquhar G D, Ehleringer J R, Hubick K T. 1989. Carbon isotope discrimination and photosynthesis. Annual Review of Plant Physiology and Plant Molecular Biology, 40(1): 503-537.

Fischer R A, Turner N C. 1978. Plant productivity in the arid and semiarid zones. Annual Review of Plant Physiology, 29(1): 277-317.

Flanagan L B, Ehleringer J R, Marshall J D. 1992. Differential uptake of summer precipitation among co-occuring trees and shrubs in a pinyon-juniper woodland. Plant, Cell and Environment, 15(7): 831-836.

Jia Z Q, Zhu Y J, Liu L Y. 2012. Different water use strategies of juvenile and adult Caragana intermedia plantations in the Gonghe Basin, Tibet Plateau. PLoS One, 7(9): e45902.

Kendall C, McDonnell J. 1998. Isotope Tracers in Catchment Hydrology. Amsterdam: Elsevier Science.

Laundré J W. 1999. Relationships between water availability, carbon isotope discrimination and plant productivity in two semi-arid grass and shrub species. Journal of Arid Environments, 41(1): 49-60.

Leng X, Cui J, Zhang S, et al. 2013. Differential water uptake among plant species in humid alpine meadows. Journal of Vegetation Science, 24(1): 138-147.

Li S G, Romero-Saltos H, Tsujimura M, et al. 2007. Plant water sources in the cold semiarid ecosystem of the upper Kherlen River catchment in Mongolia: A stable isotope approach. Journal of Hydrology, 333(1): 109-117. 
Lin G, Sternberg L S L. 1992. Comparative study of water uptake and photosynthetic gas exchange between scrub and fringe red mangroves, Rhizophora mangle L. Oecologia, 90(3): 399-403.

Lioubimtseva E, Henebry G M. 2009. Climate and environmental change in arid Central Asia: Impacts, vulnerability, and adaptations. Journal of Arid Environments, 73(11): 963-977.

Lite S J, Stromberg J C. 2005. Surface water and ground-water thresholds for maintaining Populus-Salix forests, San Pedro River, Arizona. Biological Conservation, 125(2): 153-167.

Ma J Y, Chen K, Xia D S, et al. 2007. Variation in foliar stable carbon isotope among populations of a desert plant, Reaumuria soongorica (Pall.) Maxim. in different environments. Journal of Arid Environments, 69(3): 365-374.

Newman B D, Campbell A R, Wilcox B P. 1997. Tracer-based studies of soil water movement in semi-arid forests of New Mexico. Journal of Hydrology, 196(1-4): 251-270.

Nippert J B, Knapp A K. 2007. Linking water uptake with rooting patterns in grassland species. Oecologia, 153(2): 267-272.

Ohte N, Koba K, Yoshikawa K, et al. 2003. Water utilization of natural and planted trees in the semiarid desert of Inner Mongolia, China. Ecological Applications, 13(2): 337-351.

O'Leary M. 1981. Carbon isotope fractionation in plants. Phytochemistry, 20(4): 553-567.

O'Leary M. 1988. Carbon isotopes in photosynthesis. Bioscience, 38(5): 328-336.

Rundel P W, Esler K J, Cowling R M. 1999. Ecological and phylogenetic patterns of carbon isotope discrimination in the winter-rainfall flora of the Richterveld, South Africa. Plant Ecology, 142(1-2): 133-148.

Sang X F, Zhang M Q. 2006 Visual simulation and management of groundwater in Dunhuang Basin. MSc Thesis, Lanzhou: Lanzhou University. (in Chinese)

Schwinning S, Starr, B I, Ehleringer, J R. 2005. Summer and winter drought in a cold desert ecosystem (Colorado Plateau) part I: effects on soil water and plant water uptake. Journal of Arid Environments, 60(4): 547-566.

Sternberg L S L, Swart P K. 1987. Utilization of freshwater and ocean water by coastal plants of southern Florida. Ecology, 68: 1898-1905.

Sternberg L S L, Ish-Shalom-Gordon N, Ross M, et al. 1991. Water relations of coastal plant communities near the ocean/freshwater boundary. Oecologia, 88(3): 305-310.

Stromberg J C, Bagstad K J, Leenhouts J M, et al. 2005. Effects of stream flow intermittency on riparian vegetation of a semiarid region river (San Pedro River, Arizona). River Research and Applications, 21(8): 925-938.

Valentini R, Mugnozza G E S, Ehleringer J R. 1992. Hydrogen and carbon isotope ratios of selected species of a mediterranean macchia ecosystem. Funtional Ecology, 6: 627-631.

Wang G A, Han J M, Zhou L P, et al. 2005. Carbon isotope ratios of plants and occurrences of $\mathrm{C}_{4}$ species under different soil moisture regimes in arid region of Northwest China. Physiologia Plantarum, 125(1): 74-81.

Wershaw R L, Friedman I, Heller S J, et al. 1966. Hydrogen isotopic fractionation of water passing through trees. In: Hobson G D, Speers G C. Advances in Organic Geochemistry. Oxford: Pergamon Press, 55-67.

White J W C, Cook E R, Lawrence J R, et al. 1985. The ratios of sap in trees: Implications for water sources and tree ring ratios. Geochimica et Cosmochimica Acta, 49(1): 237-246.

Yang H, Auerswald K, Bai Y F, et al. 2011. Complementarity in water sources among dominant species in typical steppe ecosystems of Inner Mongolia, China. Plant and Soil, 340: 303-313.

Yu S W, Sun Z Y, Zhou A G, et al. 2012. Determination of water sources of Gobi plants by $\mathrm{D}$ and ${ }^{18} \mathrm{O}$ stable isotopes in middle reaches of the Heihe River. Journal of Desert Research, 32(3): 717-723. (in Chinese)

Zhang M Y, Zhang M Q. 2008. Study on the carrying capacity of water resources in Dunhuang. MSc Thesis, Lanzhou: Lanzhou University. (in Chinese)

Zhao L J, Xiao H L, Cheng G D, et al. 2008. A preliminary study of water sources of Riparian in the lower reaches of the Heihe Basin. Acta Geoscientica Sinica, 29(6): 709-718. (in Chinese)

Zhou H, Zheng X J, Tang L S, et al. 2013. Difference and similarities between water sources of Tamarix ramosissima, Nitraria sibirica and Reaumuria soongorica in the southeastern Junggar Basin. Chinese Journal of Plant Ecology, 37(7): 665-673. (in Chinese)

Zhou Y D, Chen S P, Song W M, et al. 2011. Water-use strategies of two desert plants along a precipitation gradient in northwestern China. Chinese Journal of Plant Ecology, 35(8): 789-800. (in Chinese)

Zhu Y J, Jia Z Q, Lu Q, et al. 2010. Water use strategy of five shrubs in Ulanbuh Desert. Scientia Silvae Sinicae, 46(4): 15-21. (in Chinese)

Zimmermann U, Munnich K, Roether W. 1967. Downward movement of soil moisture traced by means of hydrogen isotopes. In: Stout G E. Isotope Techniques in the Hydrologic Cycle. Washington DC: Am Geophys Union, Geophys Monogr, 28-36. 